\section{Morphological and Cytological Comparisons of Eight Varieties of Trailing Lantana (Lantana montevidensis) Grown in Florida}

\author{
Carlee Steppe and Sandra B. Wilson \\ Department of Environmental Horticulture, University of Florida, Institute of \\ Food and Agricultural Sciences, P.O. Box 110675, Gainesville, FL 32611
}

\section{Zhanao Deng and Keri Druffel \\ Department of Environmental Horticulture, University of Florida, Institute of Food and Agricultural Sciences; and Gulf Coast Research and Education Center, 14625 County Road 672, Wimauma, FL 33598}

\section{Gary W. Knox \\ Department of Environmental Horticulture, University of Florida, Institute of Food and Agricultural Sciences; and North Florida Research and Education Center, 155 Research Road, Quincy, FL 32351 \\ Additional index words. invasive plants, ploidy, pollen stainability, tetraploid, triploid}

\begin{abstract}
Trailing lantana (Lantana montevidensis) is a popular low-growing ornamental plant valued for its heat and drought tolerance and continuous purple or white flowering throughout much of the year. Recently, trailing lantana was predicted to be invasive by the University of Florida/Institute of Food and Agricultural Sciences (UF-IFAS) Assessment of Non-Native Plants in Florida, and therefore not recommended for use. All cultivars fall under this designation unless proven otherwise. Eight trailing lantana varieties were obtained from wholesale growers and naturalized populations found in Texas and Australia. Plants were propagated vegetatively, finished in 4-inch pots, and planted under field conditions to determine morphological and cytological differences among varieties. Australian trailing lantana differed morphologically from the other varieties in its smaller habit, leaves (which had serrate-crenate leaf margins, and fewer appressed hairs), heavy fruiting, and cold sensitivity (observational reduced growth and flowering during winter months). Nuclear DNA content analysis suggests that Australian trailing lantana is likely a tetraploid and all other varieties evaluated were likely triploids with high levels of sterility. Pollen stainability of Australian trailing lantana was moderately high (58.83\%), whereas pollen production was rarely observed in all other varieties. Results support that there are two forms of trailing lantana, the U.S. varieties distinguished by their leaf and flower morphology, ploidy level, and the absence of fruit and viable pollen.
\end{abstract}

Received for publication 1 Aug. 2019. Accepted for publication 11 Sept. 2019.

We gratefully acknowledge funding support from the U.S. Department of Agriculture's (USDA) Agricultural Marketing Service and Florida Department of Agriculture and Consumer Services Specialty Crop Block Grant Program, Florida Fish and Wildlife Conservation Commission, and Florida Nursery and Growers and Landscape Association. The contents of this publication are solely the responsibility of the authors and do not necessarily reflect the official view of the USDA. We thank Mark Kann, Chris Harchick, Bart Schutzman, Krishna Bhattarai, Julia Rycyna, and Jackson Jablonski for technical assistance; and Megan Thomas and Adam Black for plant collection assistance.

This paper is based on a presentation given during the Annual Meeting of the Florida State Horticultural Society, which was held 9-11 June 2018, in Orlando, FL.

C.S. is the corresponding author. E-mail: csteppe@ ufl.edu. and improved pastures, trailing lantana is a restricted invasive prohibited for use by the Queensland Biosecurity Act of 2014 (Day et al., 2003; Johnson, 2007; Munir, 1996; O'Donnell, 2002). In the United States, it has escaped cultivation in seven states, including Alabama, California, Florida, Georgia, Hawaii, Louisiana, and Texas [U.S. Department of Agriculture, National Resources Conservation Service (USDA, NRCS), 2019]. In Florida, herbarium vouchers document its escape in 18 counties (Wunderlin et al., 2019). To date, trailing lantana has not been listed as a Category I or II invasive plant by the Florida Exotic Pest Plant Council (FLEPPC, 2019). However, based on a predictive test, the UF/IFAS Assessment of Non-Native Plants in Florida's Natural Areas does not recommend its use in northern, central, or southern Florida, with results concluding that it has high invasion risk (UF/IFAS Assessment, 2019). All cultivars fall under this conclusion unless proven otherwise and exempted from the ruling.

Trailing lantana is characterized by having a horizontal growth habit, with branches rooting at the nodes. Leaves are opposite, broadly ovate, and strongly aromatic when crushed. Umbel inflorescences, each containing $\approx 30$ florets, are borne on long axillary peduncles $\approx 30 \mathrm{~mm}$ in length. If present, blackberry-like fruit is drupe, each having one seed and up to two embryos. In Australia, Johnson (2007) reported two forms (cultivated and wild) of trailing lantana differing in their ability to produce fruit. The Australian weedy variety was described as having purple flowers with white throats, and the ornamental nonweedy variety (cultivated garden form) was described as having either lilac petals with white to yellow throats, or white petals with yellow throats. Although the lavender variety is more popular in the trade, there is a white-flowered form L. montevidensis forma albiflora that was collected from the wild in Brazil as early as 1944 (IPNI, 2015; San Marcos Growers, 2019). Similar to the lavender variety, the white form flowers year-round and is drought tolerant and adapted to full sun or part shade in USDA cold hardiness zones 8 to 10 (USDA, 2012).

Henderson (1969) reported that the two forms of trailing lantana in Australia also differed dramatically in pollen viability and ploidy level/chromosome number. The weedy form had $\approx 65 \%$ pollen stainability and was a tetraploid with $2 n=4 x=48$ chromosomes, whereas the garden form had extremely low pollen stainability (less than $6 \%$ ) and was a triploid with $2 n=3 x=36$ chromosomes. In India, only the triploid trailing lantana was noticed (Raghavan and Arora, 1960).

Although the introduction of new trailing lantana varieties is insignificant compared with $L$. camara, there has been some selection of the species with named patents (Google Patents, 2019). In 1990, Monrovia Nursery introduced White Lightnin ${ }^{\circledR}$ trailing lantana (L. montevidensis 'Monma') and Lavender Swirl ${ }^{\circledR}$ trailing lantana (L. montevidensis 'Monswee') that are still popular today. In 2007, Proven Winners released 
Table 1. Varieties of trailing lantana (Lantana montevidensis) evaluated for morphological and cytological comparisons. The source of plant material and contact information are shown.

\begin{tabular}{|c|c|c|}
\hline Source/variety & Contact/company & Additional information provided if available \\
\hline $\begin{array}{l}\text { Australia (AUS) trailing } \\
\text { lantana }\end{array}$ & $\begin{array}{l}\text { Megan Thomas, Queensland } \\
\text { Herbarium, Brisbane Botanic } \\
\text { Gardens }\end{array}$ & $\begin{array}{l}\text { Naturalized location in Queensland Australia, } \\
\text { Permit USDA APHIS P37-17-01621 }\end{array}$ \\
\hline $\begin{array}{l}\text { Costa Farms }(\mathrm{CF}) \\
\text { lavender trailing lantana }\end{array}$ & $\begin{array}{l}\text { Purchased through distributer, } \\
\text { Lowe's, Gainesville, FL }\end{array}$ & Costa Farms, Miami, FL \\
\hline $\begin{array}{l}\text { Hatchett Creek Farms } \\
\text { lavender trailing lantana } \\
\text { (HCTL) }\end{array}$ & $\begin{array}{l}\text { George Griffith, Hatchett } \\
\text { Creek Nurseries, Gainesville, FL }\end{array}$ & Mother plants obtained $20+$ years ago \\
\hline $\begin{array}{l}\text { Luscious }{ }^{\circledR} \text { grape trailing } \\
\text { lantana }\end{array}$ & $\begin{array}{l}\text { Jim Putman, New Products } \\
\quad \text { Manager, Proven Winners (PW) }\end{array}$ & $\begin{array}{l}\text { 'Robpwpur' is a product of a planned breeding } \\
\text { program developed by plant breeder, Robert J. } \\
\text { Roberson. It was discovered in July } 2002 \text { as a } \\
\text { naturally occurring branch mutation of Lantana } \\
\text { montevidensis 'Alba'. Base of leaf blade is cuneate } \\
\text { rather than cordate (trailing purple). Has denser } \\
\text { pubescence on lower side of the leaf blade and } \\
\text { darker violet main color on the upper side of the } \\
\text { flower. Application date: } 2007 \text { (Google Patents, 2019) }\end{array}$ \\
\hline $\begin{array}{l}\text { Riverview Farms (RF) purple } \\
\text { trailing lantana }\end{array}$ & $\begin{array}{l}\text { Rick Brown, Riverview } \\
\text { Farms, Seffner, FL }\end{array}$ & Quality Cuttings, Mexico \\
\hline $\begin{array}{l}\text { Texas (TX) lavender } \\
\text { trailing lantana }\end{array}$ & $\begin{array}{l}\text { Adam Black, Peckerwood } \\
\text { Garden, Northwest of Houston, TX }\end{array}$ & $\begin{array}{l}\text { Collected from a naturalized, abandoned, unmaintained, } \\
\text { overgrown area where it has existed in a large patch } \\
(\approx 12.2 \mathrm{~m} \text { long } \times \approx 3.7 \mathrm{~m} \text { wide) for decades }\end{array}$ \\
\hline
\end{tabular}

Table 2. Morphological comparison of eight trailing lantana varieties. Texas and Australia plants were obtained from natural populations. All other varieties were obtained from different nurseries as indicated in Table 1. Plants were grown from unrooted cuttings, finished in 4-inch pots, and planted under the same conditions. Leaf and flower morphology data were collected from opposite stems of the third or fourth node of each plant $(n=6) 20$ weeks after planting. Means followed by different letters within each column are significant at $P \leq 0.05$ as determined by Tukey's range test.

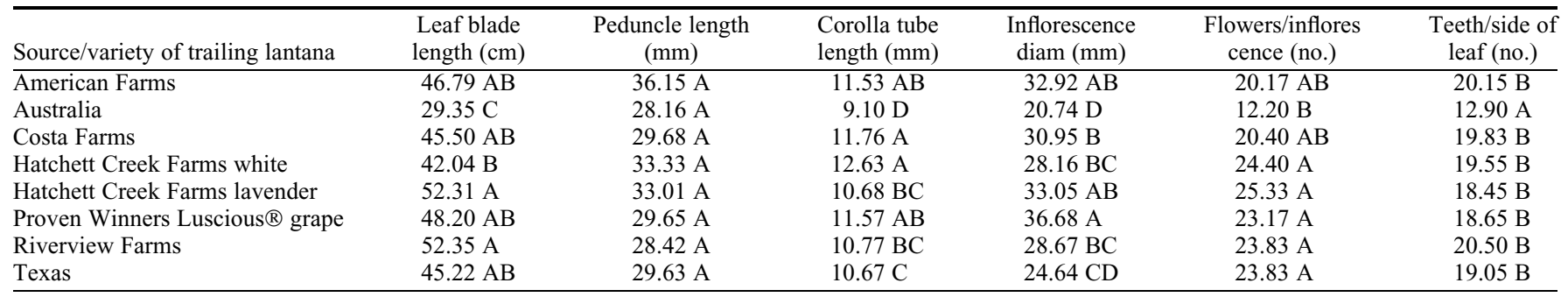

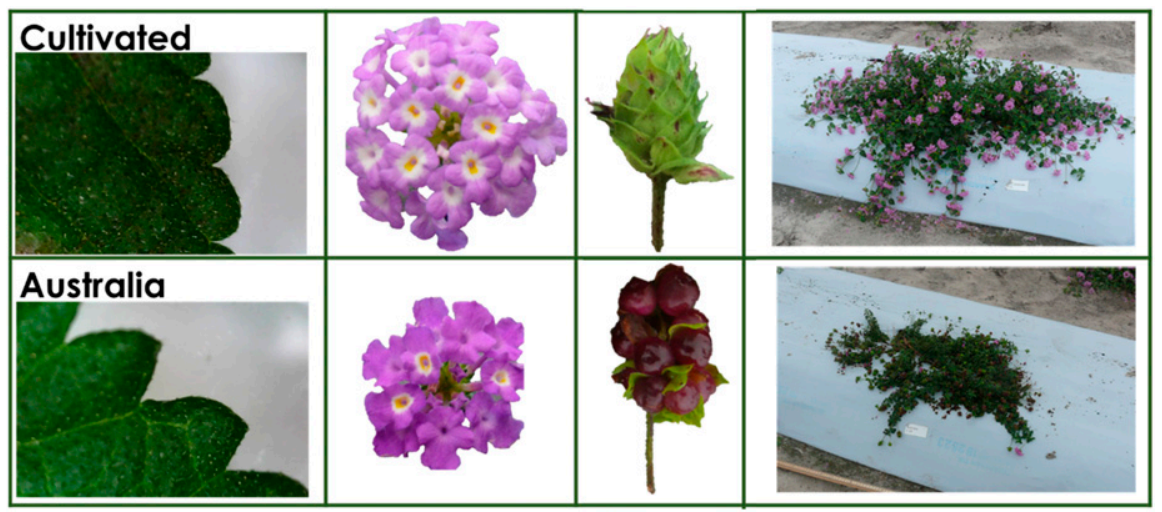

Fig. 1. Representative comparison of U.S. cultivated (top) and Australian naturalized (bottom) trailing lantana. Note differences among leaf serrations, flower number, fruiting and form. Field picture taken 20 weeks after planting. Leaf photo credit B. Schutzman.

Luscious ${ }^{\circledR}$ grape trailing lantana (L. montevidensis 'Robpwpur') and it has since received prestigious awards as a top performer from plant trials at Kansas State University, University of Georgia, Texas A\&M University, Longwood Gardens, North Carolina

HortScience Vol. 54(12) December 2019
State University, and University of Delaware. In 2013, Lord Brooks trailing lantana ( $L$. montevidensis 'Lord Brooks') was patented as a new variety distinguished by its darkercolored purple flowers. Unnamed white and lavender trailing varieties are also commonly available from nurseries throughout the United States. To our knowledge, all U.S. varieties are propagated vegetatively, as fruit is extremely rare or absent altogether. Among the known trailing lantana introductions in the United States, none have been reported from planned breeding programs for plant morphology, female sterility, pollen stainability, and/or ploidy level, such as with Lantana camara (Czarnecki et al., 2012; Deng et al., 2017).

The objective of this study was to assess morphological and cytological differences among eight trailing lantana varieties collected from different growers and a naturalized area in Texas and Australia. Information in these aspects was much needed to determine the invasive potential and suitability for continued commercial production and landscape use in the United States.

\section{Materials and Methods}

Plant material. Eight sources of trailing lantana were identified for use in this study, as described in Table 1. Four of the plant 


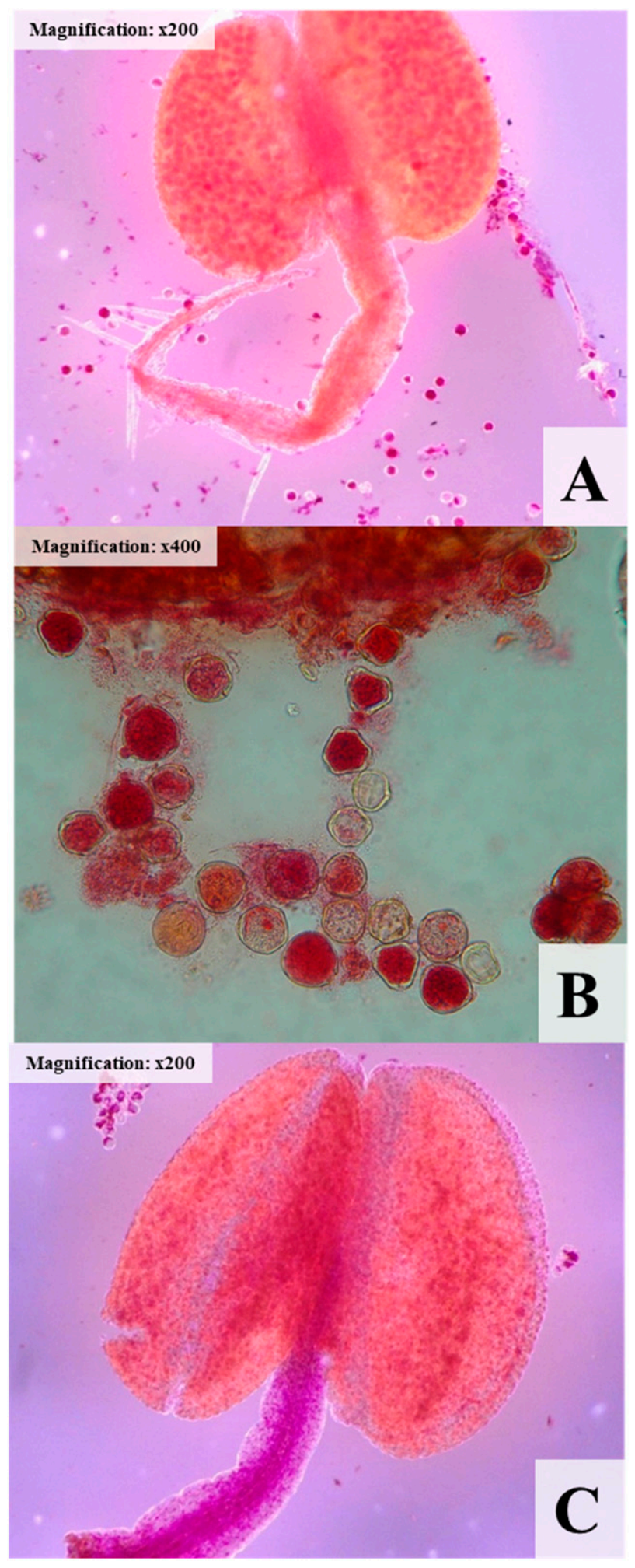

Fig. 2. Anther sac (A) and stainable pollen grains (B) of the Australian trailing lantana and Luscious ${ }^{\circledR}$ grape trailing lantana $(\mathbf{C})$ stained with acetocarmine overnight and observed under a bright field microscope at $\times 200(\mathbf{A}$ and $\mathbf{C})$ or $\times 400$ (B) magnification.

sources were nurseries based in Florida (Hatchett Creek Farms, Gainesville; Costa Farms, Miami; Riverview Farms, Riverview; and American Farms, Naples); one was a commercial breeding company (Proven Winners, Sycamore, IL), one was a naturalized area in Houston, TX; and one was a naturalized area in Queensland, Australia. Under
Permit P37-17-01621 [USDA Animal and Plant Health Inspection Service (APHIS)], vegetative plant material from Australia was shipped overnight from the Queensland Herbarium to Gainesville, FL. The Australian form was fruiting at the time of collection, and the U.S. varieties were reported to have never fruited on site. Plants were propagated at the UF/IFAS Gulf Coast Research and Education Center in Wimauma, FL. Cuttings each with 3 to 5 nodes were dipped in 2000 ppm indole-3-butyric acid talc and rooted under mist. After 4 weeks, rooted cuttings were finished in 4-inch pots filled with Fafard 2P soilless medium (Sun Gro Horticulture, Agawam, MA) and installed under full-sun conditions in north central Florida (Citra, FL; USDA cold hardiness zone 9a) on 16 July 2018. Fields were fumigated at least 1 month before planting. Plants were placed $6.0 \mathrm{ft}$ on center in raised beds covered with white on black polypropylene plastic. Plants were drip irrigated 3 to $5 \mathrm{~d}$ per week as needed; topdressed with $9 \mathrm{~g}$ (0.5 tablespoon) of 12month $15 \mathrm{~N}-3.9 \mathrm{P}-10 \mathrm{~K}$ Osmocote Plus (Scotts Co., Marysville, $\mathrm{OH}$ ), and fertigated twice a month $\left(15 \mathrm{~N}-0 \mathrm{P}_{2} \mathrm{O}_{5}-15 \mathrm{~K}_{2} \mathrm{O}\right.$; JR Peters Inc., Allentown, PA).

Plant morphology and fruit production. Leaf and flower morphology were assessed from plants of each variety grown under the same conditions and of the same age. Measurements included leaf blade length, peduncle length, corolla tube length, inflorescence diameter, number of flowers per umbel, and number of serrations per lamina, as described by Sanders (1987). For each of six plant replicates, two measurements were taken from opposite leaves 3 to 4 nodes from the apex and averaged.

Pollen stainability. Pollen stainability has been used as an indicator of lantana's male fertility (or sterility) and hybridization potential (Czarnecki et al., 2014; Deng et al., 2017; Henderson, 1969). To determine pollen stainability, anthers were collected from field-grown plants of each variety and stained in a $1.5-\mathrm{mL}$ microcentrifuge tube containing $50 \mu \mathrm{L}$ of acetocarmine (4\%) (TCI America, Portland, OR) overnight. Slides were prepared the following day by pulling the anther sacs out of the tubes with a toothpick and placing on a slide in a drop of the acetocarmine stain. Anther sacs were broken with a dental probe and swirled to release the pollen grains from the anther sacs. Then 5 to $10 \mu \mathrm{L}$ of $2 \%$ acetocarmine/glycerol (1:1) was added, a coverslip placed, and the preparation sealed with fingernail polish. The slides were observed and photographed under a bright field microscope (Olympus BH-2, Center Valley, PA) at $\times 200$ and $\times 400$ magnification. Plump, round, uniformly stained pollen grains were considered stainable, whereas misshaped, nonstained, or unevenly lightstained pollen grains were counted as nonstainable. For each variety, more than 600 pollen grains (if produced and available) were examined from four replicate samples.

Nuclear DNA content and ploidy analysis. Over the past two decades, flow cytometry has become a reliable and quick approach for determining plant ploidy levels (Bohanec, 2003). This approach has been widely used to determine the ploidy level of Lantana camara varieties (Czarnecki et al., 2012, 2014; Deng et al., 2017). In this study, the ploidy level of trailing lantana varieties was determined using a CyFlow Cube 6 flow 
Table 3. Nuclear DNA content, ploidy level, pollen production and quantity in anthers, and percent pollen stainability of eight trailing lantana varieties.

\begin{tabular}{|c|c|c|c|c|}
\hline Variety or source of trailing lantana & $\begin{array}{l}\text { Nuclear DNA content } \\
\quad \pm \mathrm{SD}(\mathrm{pg} / 2 \mathrm{C})\end{array}$ & Ploidy level & $\begin{array}{l}\text { Pollen production } \\
\text { and quantity }\end{array}$ & $\begin{array}{c}\text { Pollen stainability } \\
\pm \mathrm{SD}(\%)\end{array}$ \\
\hline American Farms & $2.80 \pm 0.06$ & Triploid & No to little, nonstainable & $-^{z}$ \\
\hline Australia & $3.98 \pm 0.03$ & Tetraploid & Numerous, most were stainable & $58.83 \pm 3.92$ \\
\hline Costa Farms & $2.91 \pm 0.04$ & Triploid & Little, misshaped, and nonstainable & - \\
\hline Hatchett Creek Farms lavender & $2.85 \pm 0.05$ & Triploid & No & - \\
\hline Hatchett Creek Farms white & $2.80 \pm 0.10$ & Triploid & No & - \\
\hline Proven Winners & $2.84 \pm 0.09$ & Triploid & No & - \\
\hline Riverview Farms & $2.85 \pm 0.04$ & Triploid & No to little, nonstainable & - \\
\hline Texas & $2.83 \pm 0.01$ & Triploid & No & - \\
\hline
\end{tabular}

${ }^{\mathrm{z}}$ Indicates pollen sacs were empty and stainable pollen grains were not observed.

cytometer (Sysmex; Partec GmbH, Münster, Germany) that was equipped with laser lights (488 nm blue and $638 \mathrm{~nm}$ red) and could allow the determination of absolute nuclear DNA contents.

The nuclear DNA content of each variety was determined using with the procedure described by Doležel et al. (2007) and modified by Cao et al. (2014). Tomato (Solanum lycopersicum 'Stupické polní rané') with a nuclear DNA content of $1.69 \mathrm{pg} / 2 \mathrm{C}$, was selected as the internal reference for use in this study. Approximately $40 \mathrm{mg}$ of fresh leaf tissues was cochopped with a similar amount of tomato leaf tissues in a petri dish in $1 \mathrm{~mL}$ of cold HB01 lysis buffer (Doležel et al., 2007). The homogenate containing lantana and tomato nuclei was filtered through a nylon mesh $(50-\mu \mathrm{m}$ pore size) into a sample loading tube with $50 \mu \mathrm{L}$ of a stock solution containing DNA fluorochrome propidium iodide (1 $\mathrm{mg} \cdot \mathrm{mL}^{-1}$; Sigma-Aldrich, St. Louis, MO) and RNase (1 mg.mL ${ }^{-1}$; SigmaAldrich). The collected suspension containing lantana and tomato nuclei was then analyzed on the flow cytometer. At least three runs were performed for each accession, and a minimum of 3000 particles were counted in each run. The nuclear DNA content of trailing lantana samples was calculated according to Doležel et al. (2007): sample nuclear DNA content $(\mathrm{pg} / 2 \mathrm{C})=$ internal reference nuclear DNA content $(1.69) \times$ (mean fluorescence value of sample / mean fluorescence value of internal reference). The ploidy level of the trailing lantana samples was determined by comparing their nuclear DNA contents with another white trailing lantana variety (from a local wholesale nursery in Tampa, FL) whose somatic chromosomes in root tip cells were counted previously (R. Qian and Z. Deng, unpublished data).

Experimental design and data analysis. Eight varieties of trailing lantana were randomized and replicated in six plant plots. A one-way analysis of variance was conducted using JMP, Version 13 (SAS Institute Inc., Cary, NC). Significant means were separated by a Tukey's honestly significant difference at $P \leq 0.05$.

\section{Results and Discussion}

Plant morphology. Leaf and flower morphology were generally similar among U.S. varieties, with the exception that Hatchett
Creek Farms' and Riverview Farms' lavender trailing lantana had longer leaf blades, Costa Farms' lavender and Hatchett Creek Farms' white trailing lantana had longer corolla tubes, and Luscious ${ }^{\circledR}$ grape trailing lantana had slightly larger inflorescence diameter compared with most other varieties (Table 2). Observationally, U.S. varieties were also very similar in landscape appearance, habit, and flowering (S. Wilson, unpublished data)

The Australian trailing lantana was morphologically distinct compared with the U.S. varieties (Fig. 1). Leaves were $54 \%$ to $78 \%$ smaller, with $43 \%$ to $59 \%$ fewer leaf serrations (Table 2), distinct serrate-crenate margins, and fewer appressed hairs (Fig. 1). Flowers were smaller in inflorescence diameter, with fewer flowers per inflorescence, and shorter corolla tube lengths (Table 2). Both the Australian and U.S. varieties had lavender petals with occasional white corolla tubes and yellow eyes, but this was more pronounced with the U.S. varieties than the Australian variety (Fig. 1).

Fruit production. Fruit production was not observed on any trailing lantana varieties from the United States. Plants of the Australian trailing lantana produced abundant fruit, on average 7.7 drupes per flower cluster (Fig. 1). The distinction of two types of trailing lantana (one fruiting and one nonfruiting) is consistent with previous literature (Johnson, 2007). Personal observations from nursery suppliers of the U.S. varieties used in this study (Table 1) reliably report plants do not fruit.

Pollen stainability. Well developed, stainable pollen grains were readily observed in the anther sacs of the Australian trailing lantana plants (Fig. 2A and B). The average pollen stainability was $58.83 \%$ (Table 3 ). Anther sacs of all U.S. trailing lantana plants rarely contained pollen grains or stainable pollen grains (Fig. 2C). This is consistent with the report by Czarnecki et al. (2014) and indicates high levels of male sterility in the U.S. trailing lantana varieties tested in this study.

Nuclear DNA content and ploidy analysis. Ploidy level is one of the most important factors in determining lantana pollen stainability/male sterility (Czarnecki et al., 2014) and fruit/seed production (Czarnecki, 2011). In this study, the average nuclear DNA content of Australian trailing lantana plants was determined to be $3.98 \mathrm{pg} / 2 \mathrm{C}$, using tomato as the internal reference (Table 3 ). All U.S. varieties had the nuclear DNA content ranging from 2.80 to $2.85 \mathrm{pg} / 2 \mathrm{C}$ (Table 3). This study represents the first report of the nuclear DNA content of trailing lantana. By comparing the nuclear DNA content of these varieties with that of a triploid lavender trailing lantana with $2 n=$ $3 x=36$, it was determined that the Australian trailing lantana is a tetraploid and all the U.S. varieties are triploids.

\section{Conclusion}

Results from this study provide evidence that the U.S. trailing lantana varieties are morphologically and cytologically distinct from the Australian weedy form of trailing lantana. The Australian weedy form is a tetraploid and highly fertile in terms of male (pollen) and female fertility, and the U.S. varieties examined in this study are triploids and highly male and female sterile. To our knowledge, the Australian variety is not grown in the United States. Measures should be taken to prevent its introduction. The U.S. varieties are highly ornamental and meet the general criteria for sustainable landscaping (drought tolerant, maintenance free, year-round flowering for pollinators). Additional studies are warranted to evaluate U.S. varieties in multiple growing areas for an extended amount of time in the presence or absence of the Australian variety in preparation of Infraspecific Taxon Protocol Requests (UF-IFAS, 2019) for potential recommended use in Florida.

\section{Literature Cited}

Bohanec, B. 2003. Ploidy determination using flow cytometry, p. 397-403. In: M. Maluszynski, K.J. Kasha, B.P. Forster, and I. Szarejko (eds.). Doubled haploid production in crop plants. Springer Publishing, Dordrecht.

Cao, Z., Z. Deng, and M. McLaughlin. 2014. Interspecific genome size and chromosome number variation sheds new light on species classification and evolution of Caladium (Araceae). J. Amer. Soc. Hort. Sci. 49:449-459.

Czarnecki, D.M. 2011. Genetic sterilization and reproductive biology of Lantana camara. University of Florida, Gainesville, PhD Diss.

Czarnecki, D.M., S.B. Wilson, G.W. Knox, R. Freyre, and Z. Deng. 2012. UF-T3 and UF-T4: Two sterile Lantana camara cultivars. HortScience 47:132-137.

Czarnecki, D.M., A.J. Hershberger, C.D. Robacker, D.G. Clark, and Z. Deng. 2014. Ploidy levels and pollen stainability of Lantana camara cultivars and breeding lines. HortScience 49:1271-1276. 
Day, M., C.J. Wiley, J. Playford, and M.P. Zalucki. 2003. Lantana: Current management status and future prospects. Austral. Ctr. Intl. Agr. Res. Canberra, Australia.

Deng, Z., S.B. Wilson, X. Ying, and D.M. Czarnecki, II. 2017. Infertile Lantana camara cultivars UF1011-2 and UF-1013A-2A. HortScience 52:652657.

Doležel, J., J. Greilhuber, and J. Suda. 2007. Estimation of nuclear DNA content in plants using flow cytometry. Nat. Protoc. 2:22332244.

Florida Exotic Pest Plant Council. 2019. Florida Exotic Pest Plant Council's 2019 list of invasive species. 20 May 2019. <https://www.fleppc.org/ list/list.htm>.

Google Patents. 2019. Lantana plant named 'Robpwpur'. 20 May 2019. <https://patents.google.com/ patent/USPP19357P2/en?q='Robpwpur'\&oq= 'Robpwpur'+>.

Henderson, R.J.F. 1969. A cytological study of Lantana montevidensis (Spreng.) Briq. in
Queensland, 1-4. Contributions from the Queensland Herbarium, No. 3. Queensland Herbarium.

International Plant Names Index (IPNI). 2015 Lantana montevidensis. 20 May 2019. <htpp:// www.ipni.org>.

Johnson, S.B. 2007. Review of the declaration of lantana species in New South Wales. Dept. Primary Ind., Orange NSW, Australia.

Munir, A.A. 1996. A taxonomic review of Lantana camara L. and L. montevidensis (Spreng.) Briq (Verbenaceae) in Australia. J. Adel. Bot. Gard. 17:1-27.

O'Donnell, C. 2002. The creeping lantana handbook. A guide to ecology, control and management. Queensland Dept. Primary Ind., Natl. Resources and Mines, Brisbane, Australia.

Raghavan, R.S. and C.M. Arora. 1960. Morphological and cytological studies in the genus Lantana L. Bull. Bot. Surv. India 2:299-303.

San Marcos Growers. 2019. Lantana montevidensis 'Alba'. 20 May 2019. <https://www.smgrowers. com/products/plants/plantdisplay.asp?plant $\mathrm{id}=925>$.

Sanders, R.W. 1987. Identity of Lantana depressa and $L$. ovatifolia (Verbenaceae) of Florida and the Bahamas. Syst. Bot. 12:44-60.

University of Florida, Institute of Food and Agricultural Sciences (UF/IFAS). Assessment of Non-Native Plants in Florida's Natural Areas. 2019. Lantana montevidensis. 20 May 2018. $<$ https://assessment.ifas.ufl.edu/assessments/ lantana-montevidensis/>.

U.S. Department of Agriculture, Agricultural Research Service. 2012. Plant hardiness zone map. 20 May 2019. <https://planthardiness.ars.usda.gov>.

U.S. Department of Agriculture, National Resources Conservation Service. 2019. The PLANTS database. Natl. Plant Data Team, Greensboro, NC. 20 May 2019. <htpp://plants.usda.gov>.

Wunderlin, R.P., B.F. Hansen, A.R. Franck, and F.B. Essig. 2019. Atlas of Florida plants. Inst. Systemic Bot., Univ. South Florida. 20 May 2019. <http://florida.plantatlas.usf.edu> 